\title{
Historiographical Overview of the Research on the Transformation of the Russian People's Values
}

\author{
Mikhail Ia. Khrebtov* and Antonina I. Fil'ko \\ Siberian Federal University \\ Krasnoyarsk, Russian Federation
}

Received 10.03.2020, received in revised form 30.04.2020, accepted 12.05.2020

\begin{abstract}
The article gives a historiographical overview of the research on transformation of the Russian people's values. It deals with the concept of "socio-cultural transformation" as the basis for the process of transformation of values in the society. The article also considers the concept of "value" presented in classical works in order to thoroughly cover the historiography of the issue of transformations of values. The issue of axiological transformation was regarded by the scholars at the intersection of or from the point of view of such fields of scientific knowledge as philosophy, history, economics, political science, sociology, psychology, cultural studies, etc. The overview focuses not on the works that analyze the values themselves, but on the research that is based on the issues and phenomena that reflect the moment, premise or cause of a social value transition, movement, revaluation, paradigm shift, formation, etc. The research overview also gives a complete picture of research on the transformation of the Russian people's values and shows some dynamics in the development of values in modern Russian society.
\end{abstract}

Keywords: transformation of values, research approaches, values, changes in the Russian people's values, Russian people's values, socio-cultural transformations.

The reported study was funded by RFBR, project No. 19-39-90015. The reported study was funded by RFBR, project No. 19-311-90017.

Research area: culturology.

Citation: Khrebtov, M.Ia., Fil'ko, A.I. (2020). Historiographical overview of the research on the transformation of the Russian people's values. J. Sib. Fed. Univ. Humanit. Soc. Sci., 13(5), 738-751. DOI: $10.17516 / 1997-1370-0603$.

\footnotetext{
(C) Siberian Federal University. All rights reserved

* Corresponding author E-mail address: khrebtov.m@mail.ru, chalkywolf@gmail.com ORCID: 0000-0002-2787-423X (Fil'ko)
} 


\section{Introduction}

In modern society, socio-cultural values are undergoing rapid changes. Former ideas about the world order no longer reflect the objective reality, including the social one. All these changes gradually lead to reassessments of the issues important for the representatives of a particular society. This is a prerequisite for a socio-cultural change of the value paradigm indicating axiological changes in the course of social development.

At the end of $20^{\text {th }}$ - beginning of $21^{\text {st }}$ centuries, modern Russian society faces a systemic crisis. Structural and institutional restructuring can form a society with a new value and spiritual basis. Social inefficiency of standards forces social groups and individuals to adapt to new socio-cultural patterns. This indicates the attitude towards the "challenges" of the social environment and also aligns expectations with innovations. Such innovations do address socio-cultural landmarks. At the end of the $20^{\text {th }}$ century, the ideology of consumption gets widely spread in Russia, which is facilitated by Western-type advertising, aimed not only at promoting specific products, but at reproducing a certain lifestyle as well as at forming certain consumer motivations. All this is reflected in the cross-section of socio-cultural orientations of the Russian society.

\section{Methodology}

An overview of various sources such as monographs, encyclopedias, articles, journalistic notes, and Internet sources. The descriptive method is applied to analyse transformation of the Russian people's values. Generalizing methods (synthesis, induction, and deduction) are also involved.

\section{Discussion}

\section{The concept of sociocultural transformation}

The study of value changes in society is difficult for scientific knowledge. The society is viewed as a socio-cultural system of values. All societies are more or less involved in the overall system in the course of interaction with different cultures. The options for value changes are very diverse. The spectrum of ongoing processes is regarded as socio-cultural dynamics of values. An important part of socio-cultural dynamics of values is socio-cultural transformations that change the entire socio-cultural system of values. In modern science, there are several different theories, approaches, and conceptions that address the issue of socio-cultural transformations, the transformations being worth considering.

The category of socio-cultural changes affects the levels of social organization and covers the spheres of society. N.N. Pimenova (2015) notes that the category of socio-cultural changes embraces the transformation of social structures, practices, the emergence of new groups or the functioning of previous groups, forms of interaction and behavior. The scholar claims that the term "socio-cultural changes" is often replaced by the concept of "modernization", which is used to analyze the processes of renewal and to consider the socio-cultural value system. Shtompka (2001) distinguishes three approaches to the concept of "modernization": a progressive social change, a complex of social, political, economic, and cultural transformations developing according to the "Western model", and a set of the underdeveloped societies' efforts aimed at "chasing" more developed civilizations.

N.N. Pimenova (2015) suggests three models of socio-cultural dynamics: a cyclic model representing the history of culture as the community's life cycle; a linear model providing an evolutionary approach to culture; and a synergetic model developed since the second half of the $20^{\text {th }}$ century.

The cyclic model of socio-cultural dynamics has two directions: the desire to describe the entire history of mankind in a single cyclic movement (Dianova, 2002) and the denial of this integrity through distinguishing autonomously developing civilizations. It is G. Viko (1994) who is considered to be the founder of this conception. The scholar viewed the cycle as a sequence of three epochs: "the age of gods", "the age of heroes|, and "the age of humans". O. Shpengler (2019) claims a single rhythm of the cycle. Yet, at the same time he distinguishes eight cultures that develop autonomously in subordination to this cycle. N.Ia. Danilevskii (2008) presents the conception of "cultural-his- 
torical types", civilizations, the existence of which is subject to the law of life cycle with four stages: birth, flourishing, decline, and death. A.Dzh. Toynbi (2001) suggests the theory of local civilizations, the main mechanism of socio-cultural changes being the so-called "challenge-and-response". L.N. Gumilev (2008) distinguishes the following phases in ethnogenesis: the incubation period, the passionary push, the acmatic phase, the fracture phase, the inertia phase, the obscuration phase, and the memorial phase. The driving forces in the process of socio-cultural changes are certain representatives of the community, the passionaries. P.A. Sorokin defines the principle of immanent change of the socio-cultural system and the derivative principle of limits. He distinguishes such characteristics of the mechanisms of socio-cultural changes as repetition, rhythm, linearity, and eternal novelty.

The linear model of socio-cultural dynamics interprets history as a progressive movement, mechanisms of sociocultural changes in the conceptions of human history as linearly developing ones being internal grounds for this path (Pimenova, 2015). G.W.F. Hegel (1990) argues that social dynamics is subject to the law of the movement of the spirit as an absolute world potency on the way for its release. O. Kont (1971) writes that the main direction of the sociocultural reality development is the progress of the human mind. Tailor (1989) suggests an evolutionary view of sociocultural transformation. He puts forward the ideas of progress and regression of culture. The human history is viewed as the evolution of nature, so the main law is the law of evolutionary development.

The paradigm approach also regards the linearity of the cultural dynamics trajectory. Yet, it focuses on the global significance of the value bases of culture and the paradigm as a cultural matrix that structures its reality (Pimenova, 2015). R. Inglehart points at the socio-economic structure and fundamental value attitudes in their constant connection and mutual movement. Transformations of cultural values are the force of changes, whereas the changes in socio-economic conditions are the impetus for their changes. A.G. Dugin (2002) defines the paradigm as a set of initial value attitudes of a cultural phenomenon, action, including thoughts, this set of attitudes organizing reality in a special way. The nature of socio-cultural transformations in the paradigm approach is manifested in the fact that it is impossible for the movement to return to the former paradigm, but there is no rigid determinism in the transformation of one cultural matrix into another.

The synergetic model of socio-cultural dynamics is based on the idea of culture as an open self-organizing system. Sociocultural transformations are changes that occur during the system transition from chaos to order in the course of a new order formation. S.P. Kurdoiumov considers synergetics as a new cultural paradigm of values and defines the bifurcation point as the branching point of the nonlinear system evolution paths. It is the bifurcation point that facilitates the detection of changes in the system, the transition to a new qualitative state. At that the transition is no longer reversible. The synergetic approach regards sociocultural changes as the process of value system transition from the previous quality to a new qualitative state through a crisis, the mechanisms of such a change being the internal cultural self-organizing forces in their reaction to changes in the environmental constants, important parameters of the socio-cultural whole.

A.N. Tarasov (2011) regards sociocultural transformation as a process of reducing the level of system-hierarchical structuring, complexity and polyfunctionality of the cultural complex as a whole, i.e. the degradation of this culture as a system. According to the scholar, socio-cultural transformation entails the loss of integrity and the balance of culture, after which it can no longer regulate the individuals' social life. Sociocultural transformation is a process of direct changes, a process of transition to a new quality.

The concept of socio-cultural transformation is referred to by Ia. Bagdasarova (2009) when considering the migrants' adaptation. The scholar links this concept to cultural diversity. Migrants who find themselves in a new cultural environment pass through a crisis in their native culture, as they are forced to adapt 
to new conditions. Yet, at the same time, they do not lose it while completely passing through the processes of acculturation, but transform it in accordance with the conditions changed.

N.A. Yankova (2016) argues that socio-cultural transformation is manifested in the change of social organization and types of reproduction of cultures as well as of the determinant strategy for the development of values in modern society. The scholar claims that these value processes can relate to the ontological characteristics of the language, its conceptual and instrumental aspects. This suggests that the language is actively involved in socio-cultural dynamics. In her dissertation E.A. Yerokhina (2015) notes that socio-cultural transformation of values, which determines the transition of the society from its traditional state to a modern one, manifests itself in the change of types of social organization and types of cultural reproduction.

Thus, the dynamics of culture organized by socio-cultural reality can hardly be generated by internal factors only, since the percentage of cultural isolation is low. Modern world is a situation of constant cultural exchange, a sharp perception of cultural boundaries, which become a field for the emergence of meanings and practices. In this case, "socio-cultural transformation" will be regarded as the process of transition of one value system to a new quality. As a result, socio-cultural transformation is often characterized by the crisis of a particular culture. Such crisis occurs when the culture cannot adapt to new conditions and is in need for radical changes.

It is the concept of "value" that is worth while considering first for a research overview.

\section{The concept of "value"}

The concept of "value" was first referred to in ancient times. Socrates made it the central point of his philosophy when framing it as "What is the good?" question. The good, according to Socrates, is the realized value utility. The philosopher believed that value and utility are two sides of the same coin. Completeness of Being was understood as an absolute value for a human, the value expressing both ethical and aesthetic ideals. In Plato's con- ception, the One or the Good was identical with Being, Good, and Beauty.

In the Middle Ages, the idea of the objective supreme value of the Absolute as the source of wisdom and all good and the human's subjective existence got its approval. On this basis, ancient values with their aspiration to the ideals of truth, good and reason were revaluated. The significance of subjective values that characterize a human's personality, such as love, faith, hope, conscience, etc., increases. Avgustin Avrelii (1989) in his work "Confessions" dwells on a human's comprehension of value not by the rational, but sensually-volitional way of discovering the uniqueness of each human's personality.

In the $19^{\text {th }}$ century, the German naturalist and philosopher G. Lotze suggested the theory of values (axiology) as a field of science. Lotze distinguishes the "world of values" and the "world of phenomena". The values, in his opinion, belong to the sphere of duty. The philosopher distinguished the field of value definition of the due from the field of phenomena of reality (facts) and their knowledge (truths). Axiology development is associated with the German classical philosophical tradition. According to Kant (1966), the values are requirements to the will; goals a human faces; significance of certain factors for the individual. The philosopher claims that the values are determined by certain goals (subjective and absolute). The value of all objects acquired through our actions is always conditioned. Objective goals, according to the philosopher, are objects the existence of which is a goal in itself, and this goal cannot be replaced by any other goal for which they should have served as a means only (Kant, 1966). Hegel defines the value as the equivalent of need, which is expressed in cost value. He elevates culture to the rank of absolute values, since it is the result of human development along the path of ascent from subjectivity to universality: "It is ... revealing the universality of thought which is the essence of the absolute value of culture" (Hegel, 1990).

The Baden school representatives regarded the concept of value as the highest philosophical category. Vindel'band interpreted the value as ideal norms that serve the basis for 
evaluating what is done with natural necessity. He claimed that the values as norms form the basis of his aesthetic and theoretical work, and that transcendental consciousness is the source of values as ideals. This means that the value is the goal. Vindel'band wrote that higher values rise above the humans' changing temporal interests and are justified by the highest spiritual reality (Vindel'band, 1993). G. Rikkert distinguishes the concepts of the value and the due. According to the scholar, when the value is related to the cognizing subject it opposes the subject as the norm and the rule in the sphere of the due. G. Rikkert emphasizes the transcendental nature of value. He introduces the category of transcendental understanding, or referring to the values when it becomes clear what is generally significant, what relates to the values. As for culture, it is also understood as a set of objects associated with generally significant values and cherished for the sake of these values (Rikkert, 1911).

T. Hobbes (2001) expands the understanding of nature of values providing economic, social, political and moral grounds, which give an economic colouring to the value. A human's value is viewed through the level of demand. Leibniz characterizes the nature of values through the prism of rationalistic philosophy. He regards the ideas of harmony, balance, and proportionality as the highest values (Leibniz, 1982).

The conception of value creation is a main one in Nietzsche's philosophy. According to the philosopher, it is not the democratic structure of society that is more correct and progressive, but the aristocratic one with the power belonging to the most charismatic, smart, energetic, strong-willed, and active people. Nietzsche claimed that it is the creation of the superman that justifies the existence of humanity. The man is not the "crown of creation", but only an intermediate in biological evolution. A new species will eventually emerge in its place, the species being the superman (Nietzsche, 2005).

In the $20^{\text {th }}$ century, axiology developed in two main directions. The first regards the values of the product of awareness of a human's biological and mental needs. Thus, the values act as objective factors. The other direction in- terprets the value as a phenomenological phenomenon. Husserl notes that instead of objects, values, goals, and auxiliary means it is the subjective experience in which they manifest themselves that is considered (Husserl, 1991).

$\mathrm{N}$. Hartmann regards the value as the entity or something that makes everything involved in it what they really are, and namely that makes them valuable (Hartmann, 1926). According to Hartmann, the proper being does not have the power to determine the humans' activity; on the contrary, the human is a trustee of value and duty in the real world. He/she is an intermediary who introduces them into reality. If the values could determine the reality from themselves, then they would determine a human and there would be no freedom (Hartmann, 1926).

Zimmel regards the values as the facts of life that turn into the cultural dimension: "the facts of life such as work and creativity become values only when they transcend the limits of their natural existence in themselves and when viewed from the point of view of certain cultural ideals" (Zimmel, 1996).

M. Heidegger criticizes the main values of the Western world: humanism, anthropocentrism, and rationalism. Questioning these values, Heidegger argues that they hinder the search for the hidden essence of Being. Developing Nietzsche's idea of value revaluation, he states the existence of nihilistic processes in the West, nihilism being regarded as the removal of values from culture (Heidegger, 2000).

Starting with M. Veber's works (1994), the center of gravity of the study of values shifts to the field of sociological sciences, in particular, to the sociology of culture and the sociology of management. Weber interprets the "worldly values" as the direction of interest peculiar to a particular era. "Higher values", according to the scholar, acquired the meaning of "timeless"; their implementation in the framework of "culture" became independent of the implementation in time. Weber regards the values as a figment of a human's imagination with its freedom of choice for developing his/her own values depending on internal motivation.

$\mathrm{N}$. Luhmann associates the values with the most preferable consequences of an action. Ac- 
cording to the researcher, communication establishes social reality; for this reason, communication within the social system determines the formation and functional characteristics of values at the local level (Luhmann, 2007).

Thus, for many centuries, "value" had quite a number of semantic meanings. This concept of value is viewed by the philosophers of different times. It is not only the concept of philosophy and sociology, since it denotes objects, phenomena, their properties, as well as abstract ideas that embody social ideals and thus act as a standard of the due. The meanings formed in the system of axiological knowledge give the values a more multi-dimensional and multi-paradigmatic character. The sphere of values is not static, thus the values undergo multiple transformations in human life. As a result, the scholars, studying the sphere of human values, consider value orientations through the aspect of their variability and dynamics.

\section{Overview of research on the changes in the Russian people's values}

In the Soviet period, the theory of values had long been considered a bourgeois idealistic doctrine. The researches on value changes in Russia got their relevance and significance during perestroika. This period resulted in significant axiological changes in Russia. The scholars responded to these changes by the search for new social facts and systematization of the applied research materials on value changes.

Russian scholars have obtained new and interesting data on the attitudes, ideals and goals of the representatives of various social groups. Known or newly suggested solutions got their problematic and debatable plane. The scholars' interests were related to the logical analysis of changes in value attitudes, as well as to the study of the dynamics of values in society. For example, N.G. Bagdasarian (Bagdasarian, 1995) studied the variability of value orientations in the students' adulthood. S.G. Klimova (1996) distinguished the value bases of identification and stratification dynamics of axiological orientations in society. I.M. Kliamkin (1994) studied liberal and democratic values. L.M. Kosareva (1987) examined the dynam- ics of value orientations. S.F. Anisimov (1988) studied the population's values of production and consumption. A.V. Andreenkova (1994) analyzed materialistic and post-materialistic values. A.O. Boronoev (1992) focused on the Russian people's mental values. N.I. Driakhlov and V.A. Davydenko (1997) studied the changes in the social and cultural values. N.E. Tikhonova (1996) analyzed the worldview values and the political process in Russia. Theoretical and empirical works of the "local" level of such Russian researchers as Z.I. Kalugina (2001), O.P. Fadeeva (1999), O.V. Novokhatskaia (2006) et al. focused on daily activities, adaptation and values of the rural population of the Novosibirsk oblast. V.A. Artemov and his co-researchers (2002) studied the rural Siberian areas in the course of the entire period of perestroika up to the 2000s.

N.I. Lapin's study of the dynamics of values of the Russians (Lapin, 2000) is of great importance. The research of the scholar and his colleagues focused on the younger generation's thinking. Since the early 1990s, there has been a change in value markers of the adolescents mainly. At the same time, the basic values were passed from generation to generation in their fairly stable configurations. The younger generation has not yet completely rejected the old generation's values. In the context of globalization and the power of the media, the young Russians' value system is likely to become increasingly autonomous. The researchers also predict that by the end of the radical socio-economic reforms of the 1990s and the stabilization of new structures and processes, it is by 2009 when the society will enter the third stage of transformation which will contain either a historical alternative of moving forward or that of rolling back.

Basing on the example of the North Caucasian culture, R.R. Nakokhova (2008) identified the principles, factors, structure, regularities and specifics of the system of value orientations of ethnos individuals. She developed a socio-psychological conception of the determinants system development and functioning, mechanisms and stages of transformation of value orientations during socio-economic crises. As per the conception, ethnogenesis of 
value orientations has a hierarchical character. The processes that lead to changes in value orientations take place at various levels: individual-personal, group, ethnic, and interethnic. There are two processes of ethnogenesis: a socio-historical shift of value orientations and a socio-psychological one. The basic mechanisms for the value system formation and development at all levels are mechanisms of adaptation, assimilation, and accommodation.

P.P. Kozhevnikov and N.V. Sidorova (2006) focus on the issue of revaluation of values by the Russians. They argue that this revaluation is due to the transitional state of the modern world, the values of modern society being highlighted and analyzed. Nowadays, according to the researchers, the conceptual basis of any value system is in basic values, which are ranked, clarified and supplemented each time. Yet, natural values, air, water, and solar energy, which are closely linked to the object world created by man, remain immutable.

I.F. Dement'eva claims that traditional family values often become an impediment to assimilation of new realities of life. The process of adaptation to new living conditions often implies active participation of the younger generation in the family. In Russian society, the way the parents recognize their children's high competence in a number of issues related to the real values of a new society is quite atypical (Dement'eva, 2004). In a transitional Russian society, it is worth while mentioning the multidirectional participation of two generations in the process of development. Therefore, at the intergenerational level, assimilation of basic values by the children results in their parents' value transformations.

In their works, V.I. Chernov (2013), A.V. Babelo (2016), A.O. Surkova (2010), V.P. Shcherbakova (2013) consider the issues of formation and development of a new human generation, pay attention to the conflict between generations and the ways they are resolved. They focus on such an important sphere of social relations as correlation of the two opposite value scales. The issue of fundamental incompatibility of different generations is also given the analysis. New standards of a new generation's social interaction do not receive the unanimous recognition due. As a result, according to the researchers, the philosophy of extreme individualism prevails. It generates a situation of uncertainty, instability, antinomianism, and inconsistency.

In her dissertation, O.S. Anisimova (2013) emphasizes that these are the values that integrate society. So, deformation processes in the sphere of values are more dangerous than changes in the economy. The Russian society faced profound changes and deformations in its socio-cultural content. They served the indicators of the violation of the continuity of value and moral orientations as human behavior regulators in post-Soviet society. This took place in the context of increasing uncertainty, crisis socialization, and the risky nature of the Russian society. Such situation leads to an increase in individualization, the victory and power of consumer society standards, and the short-term states of uncertainty in life strategies.

Tepliakov considers the process of psychological development of people's values in the Russian society of the $21^{\text {st }}$ century. The personality itself is given a priority, since it is in it the personality that reveals an active component of personal development. The moment of identification is transferred from the external value structures imposed by the society to the individual's internal spiritual potencies, i.e. self-identification is put into the forefront (Tepliakov, 2016). The psychologist claims that the social situation changes, associated with a sharp transition from one social system to another, cause the change in the value orientations system. This can lead to both productive development and collapse of the value system.

V. Petukhov states the issue of the effectiveness of social institutions. The changes in socio-economic situation and instability of the 2000 s had led to the formation of a large class that does not expect any support from the state. For them, participation in political life does not promise tangible benefits. This class faces a significant set of socio-political problems (Petukhov, 2015). Therefore, the citizens need fair, transparent rules of the game as well as laws that would allow them to work honestly and earn money. The researcher dwells on the need for impartial courts, the importance of the 
police for their health, property and peace protection, and the need for local government and social services.

N.A. Golovina and V.A. Sibireva (2016) argue that typical values of the consumer society are significant for a large part of society, the values (work, family, success, and entertainment) manifesting themselves immediately and simultaneously. Young people show high value and lifestyle differentiation. For them, age differences play a more significant role than the standard of living. These are young people for whom a certain new set of lifestyles and values has been formed. These lifestyles and values are inherent in the consumer society; they can hardly be rejected even if the economic situation gets worse. This indicates that consumerism values have been firmly internalized and have become an integral part of values.

R.N. Shmatkov shows the dynamics of value transformation towards moving away from the humanistic paradigm to the technocratic one. This is due to the loss of the significance of a workforce as the individual's most important life support. These circumstances are associated with people's orientation towards interesting work and social activities with the means of earning money and career advancement as key values (Shmatkov, 2012). This indicates a crisis in the educational function, which is getting more and more acute with decades. The problem of education, according to the researcher, is not easy to solve, since modern Russian society is divided into classes with opposite socio-economic and political interests.

In social sciences in Russia we can also distinguish the synergetic approach to studying axiological transformations in Russian society, the approach being developed in the works by academician V. Stepin (2001), research schools of V.G. Nemirovskii (2013), V.I. Kabrin (2011), I.V. Chernikova (1955), works by V.V. Vasil'kova (Vasil'kova, 2003), et al. The scholars turn their research focus on a human in his/her integrity. They take into account the aspects of how the human inner world manifests itself as well as how it is interconnected with his/her physiology, culture, social structure, and material and technical base in the development of the society.
A number of Russian researchers associate the transformation of social values with ethnic processes, including those that are peculiar for the indigenous peoples of the North, Siberia and the Far East (Avdeeva et al., 2019a; Avdeeva et al., 2019b, Berezhnova and Pimenova, 2015; Degtyarenko et al., 2019; Pchelkina, 2015). As a rule, these studies are conducted in the field, the authors applying quantitative and qualitative methods of social research (Koptseva et al., 2018; Libakova et al., 2016; Zamaraeva, 2014; Zamaraeva et al., 2019a; Zamaraeva et al., 2019b).

One of the most important conclusions the Russian researchers come to regarding the issues of social value transformation is postulating a significant role of artistic practices, including those related to the formation of artistic images. They dwell upon visual art works and ways of appropriate artistic images formation (Kolesnik, 2018; Kolesnik et al., 2018; Kolesnik et al., 2019; Koptseva and Sitnikova, 2019; Reznikova et al., 2019; Semenova, 2010; Seredkina et al., 2019; Sertakova, 2013; Sitnikova and Zhukovskaia, 2015).

As a result, a lot of empirical and theoretical research on the Russian residents' value transformation has been conducted in Russia. Many studies register the general value-normative crisis the Russians face, the crisis having the character of revaluation of previous generations' cultural, ethical, spiritual and family values. The data obtained in the researches are often interpreted as violation of continuity and transfer of socio-cultural experience from the older generation to the next one. They raise the issue of globalization values formation in the Russian society.

\section{Conclusion}

Thus, value transformations in Russia are an urgent research issue nowadays. It is given a multidisciplinary consideration within the scientific fields of philosophy, history, economics, political science, sociology, psychology, and cultural studies. The researches on axiological changes reflect socio-cultural dynamics, which is manifested in the form of socio-cultural transformation. Classical scholars applied various approaches to the analysis of the issue. 
Later such branch of science as axiology was introduced.

This field of science has its own history in Russian scientific research. The article reviews the researches on axiological changes in the Russian society. These are the issues of the modern generation's worldview formation that often become the subject of the research. The issues usually cover the processes of education and development of young people as well as the complexity of interaction between the younger generation and their parents. The family issue is considered to be a particularly important focus of analysis in modern Russia, the phenomenon of the interethnic family being highlighted. In their works many researchers willingly dwell on characteristic features of the local process of variability and dynamics of values the residents of the country's specific regions display. Most researchers claim that, on the one hand, there still exist Soviet values in the Russian population's mass consciousness. Yet, on the other hand, a new structure of value consciousness is being modeled. The impact of cultural values of the consumer society is highlighted. This contributes to the predominance of the individual benefits over the public ones. The researchers consider the issue of weak efficiency the public management institutions demonstrate in the social sphere. To date, the scholars are unanimous when stating that the issue of transformation of values in Russia has not been given a thorough analysis yet. Therefore, this issue is in the focus of continuous studies by the researches from different fields of science.

\section{References}

Andreenkova, A.V. (1994). Materialisticheskie/postmaterialisticheskie tsennosti v Rossii [Materialistic/post-materialistic values in Russia]. In Sotsiologicheskie issledovaniia [Sociological studies], 11.

Anisimov, S.F. (1988). Dukhovnye tsennosti: proizvodstvo i potreblenie [Spiritual values: production and consumption]. Moscow.

Anisimova, O.S. (2013). Transformatsiia tsennostnykh orientatsii kul'tury postsovetskogo obshchestva: dissertatsiia ... kandidata filosofskikh nauk [Transformation of value orientations in the culture of post-Soviet society: PhD thesis]. Rostov-na-Donu, $142 \mathrm{p}$.

Artemov, V.A. (2002). Selo 90-kh godov: tendentsii povsednevnoi deiatel'nosti sel'skogo naseleniia [Village of the 90s: trends in the daily activities of the rural population]. In Sotsiologicheskie issledovaniia [Sociological studies], 126-133.

Avdeeva, Yu.N., Degtyarenko, K.A., Pchelkina, D.S., Shimanskaya, K.I., Koptseva, N.P., Shpak, A.A. (2019a). Religion of the Selkups and the Kets in the historical and cultural genesis. In J. Sib. Fed. Univ. Humanit. soc. sci., 12(5), 726-751.

Avdeeva, Yu.N., Degtyarenko, K.A., Koptseva, N.P., Pchelkina, D.S., Shimanskaya, K.I., Shpak, A.A. (2019b). Spetsifika religioznogo soznaniia ketov i sel'kupov v kontekste kul'turnogo i istoricheskogo razvitiia [The specificity of religious consciousness of the Kets and Selkups in the context of cultural and historical development]. In Severnye Arkhivy $i$ Ekspeditsii [Northern Archives and Expeditions], 3 (3), 63-80.

Avgustin, Avrelii (1989). Ispoved'. Odissei. Chelovek v istorii [Confession. Odysseus. The human in history]. Moscow.

Babelo, A.V. (2016). Istoriko-sopostavitel'nyi metod v sotsiologicheskikh issledovaniiakh [Historical and comparative method in sociological research].

Bagdasarian, N.G. (1995). Innovatsii v tsennostnykh orientatsiiakh studentov [Innovations in student value orientations]. In Sotsiologicheskie issledovaniia [Sociological studies], (4), 125-129.

Bagdasarova, Ia. (2009). Sotsiokul'turnaia transformatsiia migrantov v inokul'turnoi srede: dis. [Migrants' sociocultural transformation in foreign cultural environment]. Sankt-Peterburgskii gosudarstvennyi universitet.

Berezhnova, M.I., Pimenova, N.N. (2015). Migratsiia kak sredstvo razvitiia territorii: istoricheskii primer Kolymskogo kraia [Migration as a means of the territory development: historical examples of the 
Kolyma region]. In Sovremennye problemy nauki i obrazovaniia [Modern problems of science and education], 1-1, 1886.

Besacier, L., Zhou, B., Gao, Y. (2006). Towards speech translation of non-written languages. In IEEE Spoken Language Technology Workshop. IEEE, $225 \mathrm{p}$.

Bird, S. (2010). A scalable method for preserving oral literature from small languages. In International Conference on Asian Digital Libraries. Springer, Berlin, Heidelberg, 5-14.

Boronoev, A.O. (1992). Rossiia i russkie: kharakter naroda i sud'by strany [Russia and the Russians: the nature of the people and the fate of the country]. St. Petersburg.

Burkhanova, F.B. (2010). Etnokul'turnye resursy regiona: etnicheskaia identichnost' vykhodtsev iz mononatsional'nykh i mezhnatsional'nykh semei [Ethnocultural resources of the region: ethnic identity of immigrants from mono-ethnic and interethnic families]. In Sbornik materialov mezhdunarodnoi nauchno-prakticheskoi konferentsii [Proceedings of the international scientific-practical conference], 171-175.

Chernov, V.I. (2013). Sotsiologicheskii analiz izmenenii tsennostnykh orientatsii molodezhi [Sociological analysis of changes in the value orientations of youth].

Chernikova I. V. (1955) O dialektike abstraktnogo i konkretnogo v nauchno-teoreticheskom poznanii[On the dialectics of the abstract and the concrete in scientific and theoretical knowledge], In Voprosy filosofii [Questions of Philosophy], (1) $42-56 \mathrm{p}$.

Danilevskii, N.Ia. (2008). Rossiia i Evropa [Russia and Europe]. Institut russkoi tsivilizatsii, 816 p.

Degtyarenko, K.A., Metlyaeva, S.V., Pchelkina, D.S., Fil'ko, A.I., Shpak, A.A., Khrebtov, M. Ya., Shimanskaya, K.I. (2019). Overview of relevant regional culture studies (the Krasnoyarsk Krai): challenges and approaches. In J. Sib. Fed. Univ. Humanit. soc. sci., 12(8), 1568-1588. DOI: 10.17516/1997-1370-0465.

Dement'eva, I.F. (2004). Transformatsiia tsennostnykh orientatsii v sovremennoi rossiiskoi sem'e [Transformation of value orientations in a modern Russian family]. In Bulletin of peoples' friendship university of Russia, (6-7), 150-160.

Dianova, V.M. (2002). Kontseptsiia tsiklicheskogo razvitiia kul'tury Dzhambattisty Viko i eie posledovateli [The concept of cyclical development of the culture of Jambattista Vico and its followers]. In Sankt-Peterburgskoe filosofskoe obshchestvo [St. Petersburg Philosophical Society], (2), 43-56.

Dosakaev, A.B. (2015). Bespis'mennye iazyki korennykh malochislennykh narodov Severnogo Kavkaza: konstitutsionno-pravovoi analiz [Non-written languages of the indigenous peoples of the North Caucasus: constitutional analysis]. In Obshchestvo i pravo [Society and Law], 1 (51).

Driakhlov, N.I., Davydenko, V.A. (1997). Sotsiokul'turnye tsennosti rossiian: vchera, segodnia, zavtra [Sociocultural values of the Russians: yesterday, today, tomorrow]. In Sotsiologicheskie issledovaniia [Sociological studies], (7).

Dugin, A.G. (2002). Evoliutsiia paradigmal'nykh osnovanii nauki [The evolution of the paradigmatic foundations of science]. Moscow, Arktogeia-Tsentr, 38-39.

Dugin, A.G. (2007). Geopolitika postmoderna. Vremena novykh imperii. Ocherki geopolitiki XXI veka [Geopolitics of postmodernism. Times of new empires. Essays on the XII Century Geopolitics]. St. Petersburg, Amfora, $382 \mathrm{p}$.

Fadeeva, O.P., Shanin, T. (1999). Mezhsemeinaia set': mekhanizmy vzaimopodderzhki v rossiiskom sele [Interfamily network: mechanisms of mutual support in the Russian village]. Neformal'naia ekonomika: Rossiia i mir [Informal economy: Russia and the world]. Moscow, Logos, 183-218.

Fedina, N.N. (2017). Bespis'mennyi chalkanskii iazyk [Unwritten Chalkan language]. In Iazyki Malochislennykh Narodov Rossii [Languages of the Indigenous Peoples of Russia], 62-64.

Hobbes, Th. (2001). Leviafan, ili Materiia, forma i vlast' gosudarstva tserkovnogo i grazhdanskogo [Leviathan, or the Matter, Forme and Power of a Common-Wealth Ecclesiastical and Civil]. Moscow, Mysl', $478 \mathrm{p}$.

Golovin, N.A., Sibireva, V.A. (2016). O vozmozhnosti kul'turnoi retsessii v Rossii 2010-kh gg.: razmyshleniia nad issledovaniiami tsennostei [The possibility of cultural recession in Russia since 2010: reflections on value research]. In Zhurnal Sotsiologii i Sotsial'noi Antropologii [The Journal of Sociology and Social Anthropology], 80-94. 
Mikhail la. Khrebtov and Antonina I. Fil'ko. Historiographical Overview of the Research on the Transformation...

Gumilev, L.N. (2008). Etnogenez i biosfera zemli [Ethnogenesis and biosphere of the earth]. Moscow, Eksmo, 733 p.

Hartmann, N. (1926). Ethik. Berlin, De Gruyter.

Hegel, G.W.F. (1990). Filosofiia prava [Philosophy of Law]. Moscow.

Heidegger, M. (2000). Polozhenie ob osnovanii [The Principle of Reason]. St. Petersburg.

Husserl, E. (1991). Fenomenologiia [Phenomenology]. Moscow, Logos (1).

Engovatov, M.V. (2006). Dinamika pritiazanii i izmenenie resursnykh strategii molodezhi (1985-2005 gody) [The dynamics of claims and changes in youth resource strategies (1985-2005)]. In Otechestvennye zapiski [Domestic notes], 76-96.

Kabrin V. I. (2011) Transkommunikatsiya: preobrazovaniye zhiznennykh mirov cheloveka [Transcommunication: the transformation of human life worlds. Publisher], Izd-vo: Tom. un-ta Kollektivnaya monografiya posvyashchena klyuchevomu fenomenu postneklassicheskoy nauki i kul'tury postmoderna - transkommunikatsii [The collective monograph is devoted to the key phenomenon of post-non-classical science and postmodern culture - transcommunication], $400 \mathrm{p}$.

Kant, I. (1966). Kritika sposobnosti suzhdeniia. V 6 t. T. 5. [Critique of judgment ability. In 6 vol. Vol. 6]. Moscow.

Kalugina Z.I. (2001) Paradoksy agrarnoy reformy Rossii: sotsiologicheskiy analiz transformatsionnykh protsessov [Paradoxes of Russia's Agrarian Reform: A Sociological Analysis of Transformational Processes] Novosibirsk: IEOPP SO RAN.

Klimova, S.G. (1996). Izmeneniia tsennostnykh osnovanii identifikatsii [Changes in the value basis of identification]. In Sotsiologicheskie issledovaniia [Sociological studies], (1).

Kliamkin, I.M. (1994). Politicheskii kurs El'tsina: predvaritel'nye itogi [Yeltsin's political course: preliminary results]. In Politicheskie issledovaniia [Political Studies], (3).

Kolesnik, M.A. (2018). Filosofskie aspekty poniatiia "kul'turnaia identichnost"” [Philosophical aspects of the concept of "cultural identity"]. In Sibirskii antropologicheskii zhurnal [Siberian Anthropological Journal], 2 (2), 22-33.

Kolesnik, M.A., Leshchinskaya, N.M., Sertakova, E.A. (2019). Obraz poeta-tvortsa v simvolizme Giustava Moro [Image of the poet-creator in the symbolism of Gustave Moreau]. In Sibirskii antropologicheskii zhurnal [Siberian Anthropological Journal], 4 (12), 25-37.

Kolesnik, N.M., Libakova, N.M., Sertakova, E.A. (2018). Art education as a way of preserving the traditional ethnocultural identity of indigenous minority peoples from the North, Siberia and the Far East. In Science for Education, 8 (4), 233-247.

Kont, O. (1971). Kurs pozitivnoi filosofii. T. 3 [Positive Philosophy Course. Vol. 3]. In Antologiia mirovoi filosofii [An anthology of world philosophy]. Moscow, Mysl', 553-586.

Koptseva, N.P. (2017). Ekspertnaia ekologicheskaia otsenka, spetsifichnaia dlia korennykh narodov Sibirskoi Arktiki (na osnove Krasnoiarskogo kraia) [Expert Environmental Assessment, Specific for Indigenous Peoples of Siberian Arctic (on the Basis of Krasnoyarsk Region)]. In Ekologiia cheloveka [Human Ecology], 6, 30-35.

Koptseva, N.P., Amosov, A.E., Il'beikina, M.I., Evseenko, E.A., et al. (2018). Novye proekty dlia vozrozhdeniia evenkiiskogo iazyka i kul'tury [New projects for the revival of the Evenki language and culture]. Krasnoyarsk, Sibirskii federal'nyi universitet, 246 p.

Koptseva, N.P., Sitnikova, A.A. (2019). The historical basis for the understanding of a state in modern Russia: a case study based on analysis of components in the concept of a state, established between the fifteenth and sixteenth centuries. In International Journal for the Semiotics of Law, 32 (1), 47-74.

Kosareva, L.M. (1987). Tsennostnye orientatsii i razvitie nauchnogo znaniia [Value orientations and the development of scientific knowledge]. In Voprosy filosofii [Philosophy Issues], (8).

Kozhevnikov, P.P., Sidorova, N.V. (2006). Filosofskoe osmyslenie transformatsii tsennostei [Philosophical Understanding of the Transformation of Values]. In Vestnik YAGU [Bulletin of YAGU], 3, (2), 78-84.

Lapin, N.I. (2000). Puti Rossii [Ways of Russia]. Moscow RAN. 
Leibniz, G.V. (1982). Sochineniia: v 4 t. T. 1 [Collected works: in 4 vol. Vol. 1]. Moscow.

Libakova, N.M., Sertakova, E.A., Kolesnik, M.A., Sitnikova, A.A., Il'beikina, M.I. (2016). Sovremennye strategii sotsial'nogo pozitsionirovaniia Sibirskikh regionov [Modern strategies of social positioning of the Siberian regions]. In Sotsiodinamika [Sociodynamics], 1, 162-189. DOI: 10.7256/2409-7144.2016.1.17420. Available at: http://e-notabene.ru/pr/article_17420.html

Luhmann, N. (2007). Sotsial'nye sistemy. Ocherk obshchei teorii [Social systems. Essay on the general theory]. St. Petersburg, Izdatel'stvo «Nauka».

Lokova, M.Iu. (2007). Transformatsiia tsennostnogo mira rossiiskoi molodezhi na rubezhe 80-90-kh gg. (sotsial'no-filosofskie aspekty) [Transformation of the value world of the Russian youth at the turn of the 80s-90s (socio-philosophical aspects)]. Moscow, MosGU, 87-94.

Nakokhova, R.R. (2008). Kontseptsiia transformatsii tsennostnykh orientatsii v novoi sotsiokul'turnoi srede [The conception of transformation of value orientations in the new sociocultural environment]. In Prakticheskaia etnopsikhologiia: aktual'nye problemy i perspektivy razvitiia [Practical Ethnopsychology: Actual Problems and Development Prospects], $608 \mathrm{p}$.

Nemirovskii, V.G. (2013). Tsennostnye i sotsial'no-soslovnye prepiatstviia na puti sotsiokul'turnoi modernizatsii Rossii i ee regionov [Value and social-class barriers to the socio-cultural modernization of Russia and its regions]. In Monitoring obshchestvennogo mneniia: ekonomicheskie i sotsial'nye peremeny [Monitoring of Public Opinion: Economic and Social Changes], 4 (116), 057-070.

Nietzsche, F. (2005). Polnoe sobranie sochinenii: V 13 tomakh [Complete Works: In 13 Volumes]. Moscow, RAN.

Novokhatskaia, O.V. (2006). Sel'skaia povsednevnost' v 1970-2000 gody: dannye k analizu. [Rural everyday life in 1970-2000: data for analysis]. In Ekonomicheskoe razvitie Rossii [Economic development of Russia]. Novosibirsk, 205-233.

Pchelkina, D. (2015). Mekhanizm formirovaniia lichnostnoi interpretatsii v sotsial'nom prostranstve khudozhestvennoi kul'tury [The mechanism of formation of personal interpretation in the social space of art culture]. In Sotsiodinamika [Sociodynamics], 8, 38-63. DOI: 10.7256/2409-7144.2015.8.16108. Available at: https://nbpublish.com/library_read_article.php?id=16108

Petukhov, V.V. (2015). Rossiiskaia transformatsiia i obshchestvennaia moral' [Russian transformation and public morality]. In Sotsiologicheskie issledovaniia [Sociological studies], (12), 28-40.

Pimenova, N.N. (2015). Mekhanizmy sotsiokul'turnykh izmenenii korennykh etnosov severa i Sibiri (sotsial'no-filosofskii analiz) [The mechanisms of sociocultural changes of the indigenous ethnic groups of the North and Siberia (socio-philosophical analysis)]. Krasnoyarsk, Sibirskii federal'nyi universitet.

Reznikova, K.V., Sitnikova, A.A., Zamaraeva, Y.S. (2019). Filosofiia iskusstva v tvorchestve Egona Shile [The philosophy of art in the work of Egon Schiele]. In Sibirskii antropologicheskii zhurnal [Siberian Anthropological Journal], 4 (12), 38-48.

Rikkert, G. (1911). Nauki o prirode i nauki o kul'ture [Natural sciences and cultural sciences]. St. Petersburg.

Romanova, K.S. (2008). Transformatsiia tsennostei kak indikator izmeneniia obshchestva i lichnosti [Transformation of values as the sign of changes in society and personality]. In Nauchnyi ezhegodnik filosofii i prava Ural'skogo otdeleniia Rossiiskoi akademii nauk [Scientific Yearbook of Philosophy and Law of the Ural Branch of the Russian Academy of Sciences], (8), 165-179.

Semenova, A.A. (2010). Modern Practices of Foresight Research of the Future of Social-Anthropological Systems, Including Ethnical Cultural Populations. In J. Sib. Fed. Univ. Humanit. soc. sci., 5(3), 667-676.

Seredkina, N.N., Kistova, A.V., Pimenova, N.N. (2019). Tri kartiny Edvarda Munka: filosofsko-iskusstvovedcheskii analiz tsikla "Friz zhizni" [Three paintings by Edward Munch: philosophical and art analysis of the cycle "Frieze of life"]. In Sibirskii antropologicheskii zhurnal [Siberian Journal of Anthropology], 4 (12), 49-64.

Sertakova, E.A. (2013). Sotsial'nyi konstruktivizm kak teoriia konstruirovaniia etnosa [Social constructivism as a theory of ethnic design]. In Sovremennye problemy nauki i obrazovaniia [Modern problems of science and education], 6, 999. 
Shcherbakova, V.P. (2013). Transformatsiia tsennostnykh orientatsii molodezhi kak pokazatel' eio sotsial'noi adaptatsii [The transformation of values of youths as the indicator of their social adaptation]. In Proceedings of the TSU.

Shmatkov, R.N. (2012). Antikrizisnoe upravlenie ekonomikoi putem formirovaniia intellektual'nogo kapitala rabotnikov [Crisis management of the economy through the formation of intellectual capital of workers]. In Vestnik Sibirskogo gosudarstvennogo universiteta putei soobshcheniia [Bulletin of the Siberian State University of Railways]. Novosibirsk, SGUPSa, (27), 127-131.

Shpengler, O. (2019). Zakat Evropy. Ocherki morfologii mirovoi istorii. Tom 2 [The decline of Europe. Essays on the morphology of world history. Volume 2]. In Vsemirno-istoricheskie perspektivy [World historical perspectives], Popurri, $704 \mathrm{p}$.

Shtompka, P. (2001). Sotsial'noe izmenenie kak travma [Social change is like trauma]. In Sotsiologicheskie issledovaniia [Sociological studies], (1), 6-16.

Sitnikova, A.A., Zhukovskaia, L.N. (2015). Visualization of the Essence (about the Creative Work of the Artist Vladimir Zhukovsky). In J. Sib. Fed. Univ. Humanit. soc. sci., 1(8), 137-144.

Surkova, A.O. (2010). Sostoianie i tendentsii nravstvennykh tsennostei studenchestva [Status and trends of moral values of students].

Stepin V. S. (2001) Teoreticheskoye znaniye [Theoretical knowledge], In Voprosy filosofii [Questions of Philosophy]. № 1.

Tarasov, A.N. (2011). Sushchnost' kontsepta "sotsiokul'turnaia transformatsiia", Istoricheskie, filosofskie, politicheskie i iuridicheskie nauki, kul'turologiia i iskusstvovedenie [The essence of the concept of "sociocultural transformation"]. In Istoricheskie, filosofskie, politicheskie i iuridicheskie nauki, kul'turologiia i iskusstvovedenie. Voprosy teorii i praktiki [Historical, philosophical, political and legal sciences, cultural studies and art history. Questions of theory and practice], (7-2), 211-213.

Tailor, E.B. (1989). Pervobytnaia kul'tura [Primitive culture]. Moscow, Politizdat, 573 p.

Tepliakov, N.N. (2016). Psikhologiia samosoznaniia lichnosti [Psychology of personality identity]. Odessa, $87 \mathrm{p}$

Tikhonova, N.E. (1996). Mirovozzrencheskie tsennosti i politicheskii protsess v Rossii [Worldview Values and the Political Process in Russia]. In Obshchestvennye nauki i sovremennost' [Social Sciences and Contemporary World], (4).

Toynbi, A.Dzh. (2001). Postizhenie istorii [Comprehension of history]. Moscow, Rol'f, 640 p.

Vasil'kova V. V. (2003) Sinergetika i sotsiologicheskiy evolyutsionizm [Synergetics and sociological evolutionism], In Sinergeticheskaya paradigma. Chelovek i obshchestvo v usloviyakh nestabil'nosti [Synergetic paradigm. Man and society in conditions of instability], Moscow, Progress-Traditsiya.

Veber, M. (1994). Izbrannoe. Obraz obshchestva [Selected works. The image of society]. Moscow, Iurist.

Viko, Dzh. (1994). Osnovaniia novoi nauki ob obshchei prirode natsii [Foundations of a new science on the common nature of nations]. Kiev, $637 \mathrm{p}$.

Vindel'band, V. (1993). Filosofia v nemetskoi dukhovnoi zhizni XIX stoletiia [Philosophy of German spiritual life of the XIX century].

Yankova, N.A. (2016). Sotsiokul'turnaia transformatsiia sovremennogo obshchestva skvoz' prizmu kontseptual'nogo i instrumental'nogo aspektov iazyka [The sociocultural transformation of the modern society in the context of conceptual and instrumental aspects of language]. In Obshchestvo: filosofiia, istoriia, kul'tura [Society: philosophy, history, culture], (12).

Yerokhina, Ye.A. (2015). Etnicheskoe mnogoobrazie v sotsiokul'turnoi dinamike Rossii: dis. d-ra filos. nauk [Ethnic diversity in the sociocultural dynamics of Russia: PhD thesis]. Novosibirsk, $451 \mathrm{p}$.

Zamaraeva, Y.S. (2014). Osobennosti etnicheskoi migratsii v sotsial'no-psikhologicheskom vospriiatii (na materiale analiza rezul'tatov eksperimenta po metodike "Seriinye tematicheskie assotsiatsii") [Peculiar features of ethnic migration in socio-psychological perception (based on the analysis of the results of the experiment according to the technique of "Serial thematic associations")]. In Sotsiodinamika [Sociodynam$i c s]$, 9, 63-82. DOI: 10.7256/2306-0158.2014.9.13407 Available at: https://nbpublish.com/library_read_article.php?id=13407 
Zamaraeva, Yu.S., Luzan, V.S., Metlyaeva, S.V., Seredkina, N.N., Koptseva, N.P., Fil'ko, A.I., Khrebtov, M.Ya. (2019a). Religion of the Evenki: history and modern times. In J. Sib. Fed. Univ. Humanit. soc. sci., 12(5), 853-871.

Zamaraeva, Yu.S., Luzan, V.S., Metlyaeva, S.V., Seredkina, N.N., Fil'ko, A.I., Khrebtov, M.Y. (2019b). Rol' religii v sokhranenii traditsionnogo obraza zhizni evenkov. In Severnye Arkhivy i Ekspeditsii [North Archives and Expeditions], 3 (3), 34-47.

Zimmel', G. (1996). Izbrannoe. T. 2 [Selected Works. Vol. 2]. In Sozertsanie zhizni [Contemplation of life]. Moscow.

\title{
Историографический обзор исследований трансформаций ценностей российского населения
}

\author{
М.Я. Хребтов, А.И. Филько \\ Сибирский федеральный университет \\ Российская Федераичи, Красноярск
}

\begin{abstract}
Аннотация. Статья посвящена историографическому обзору исследований трансформаций ценностей российского населения. В статье разбирается понятие «социокультурная трансформация» как основа для процесса трансформации ценностей в обществе. Для полного понимания историографии проблематики трансформаций ценностей в статье рассматривается понятие «ценность» в работах классиков. Вопроса аксиологической трансформации ученые касались на пересечении или с точки зрения таких научных дисциплин, как философия, история, экономика, политология, социология, психология, культурология и т.д. В обзоре делается акцент не на работах, в которых ученые разбирают сами ценности, а на исследованиях, где основу составляют вопросы, явления, феномены, отображающие момент, предпосылку или причину общественного ценностного перехода, движения, переоценки, смены парадигмы, формирования и т.д. В конце обзора представлена целостная картина исследований трансформации ценностей россиян, а также дана некая динамика развития ценностей жителей современного российского общества.
\end{abstract}

Ключевые слова: трансформация ценностей, исследовательские подходы, ценности, изменения ценностей россиян, ценности российского населения, социокультурные трансформации.

Исследование выполнено при финансовой поддержке РФФИ в рамках научного проекта № 19-39-90015. Исследование выполнено при финансовой поддержке РФФИ в рамках научного проекта № 19-311-90017.

Научная специальность: 24.00.00 - культурология. 